The Canadian Journal of Higher Education, Vol. XXIV-1, 1994

La revue canadienne d'enseignement supérieur, Vol. XXIV-1, 1994

\title{
Academic Labour Markets: Perspectives from Ontario
}

\author{
GERALD ROSENBLUM* \& \\ BARBARA RUBIN ROSENBLUM*
}

\begin{abstract}
Segmented labour market thinking is utilized, as are working definitions of internal and external labour markets relative to the university as employing organization, in a study of the deployment of instructional staff at one mid-sized Ontario university. Specific categories of students are found to be disproportionately served by members of one or another of these market segments. Pronounced differences are discerned with respect to age and gender relative to labour market location. Statistics Canada data are utilized to demonstrate wide variations in the use of external labour market instructors over time within and between universities. Implications are discussed.
\end{abstract}

\section{Résumé.}

Une étude de répartition des chargés de cours d'une université ontarienne de taille moyenne révèle que l'établissement en tant qu'employeur, envisage le marché du travail de façon segmentée et utilise des concepts pragmatiques pour définir les marchés intérieur et extérieur de l'emploi.

L'étude conclut que certaines catégories spécifiques d'étudiants sont desservis de manière disproportionnée par les membres de l'un ou l'autre de ces segments du marché. Elle met également en évidence des différences profondes liées à l'âge et au sexe qui déterminent l'accessibilité à ce marché du travail. De plus, l'étude s'appuie sur les données de Statistiques Canada pour démontrer

* McMaster University 
que les méthodes de recours aux services de chargés de cours recrutés sur le marché extérieur ont varié dans le temps à l'intérieur d'une même université et entre les universités. L'article conclut en explorant les implications des résultats de cette étude.

\section{Introductory Remarks and Conceptual Framework}

A major goal of the research reported here has been to establish procedures whereby reliable data on non-tenure-stream academics might be generated. Until quite recently, there has been a void in routine information on such academics (especially part-timers) available from either the universities that employ them or government agencies that collect information from the universities. The increasing interest in the issue of non-tenure-stream academics has given rise to a growing number of efforts to fill this void. Statistics Canada, which has been approached from several quarters over the years to include part-timers in their annual data collection operations, has lately begun to attempt to do so. Also, a number of studies that include non-tenure-stream instructors have recently been completed or are currently underway. ${ }^{1}$ Thus, the omission of these instructors from studies and discussions of academia, and the distortions caused by such omissions, are beginning to be remedied along a number of fronts, and the present effort is seen as a contribution to this emerging literature.

However, it must be noted that in many discussions of faculty and universities, non-tenure stream instructors are either mentioned in passing or not at all. Their "invisibility" has been noted by those who do focus upon them (Tuckman et al., 1978, p. 186; Leslic et al., 1982, p. 72; Gappa, 1984, p. 8; Rajagopal \& Farr, 1992, p. 318), and it is hoped that recent research and concern soon provides them with attention commensurate with their numbers.

Our methodological agenda to produce data on a traditionally neglected portion of the professoriate is itself informed by theoretical issues which derive from segmented labour market thinking. Occupational and organizational labour market distinctions have been present from early on in this literature and distinguish boundaries that demarcate what one does (the occupational labour market) and where one does it (the organizational labour market). ${ }^{2}$ Each of these domains possesses boundaries and hence an "internal" labour market that is thereby enclosed. The boundaries of the occupational domain have to do with various credentialed, portable skills. On the organizational side, they pertain to seniority provisions and the related accumulated experience that accompanies elapsed time in a specific work setting and which is part of the basis for ascending job ladders. 
These internal jurisdictions provide the inhabitants with what Freedman refers to as competitive "shelters" (1976) relative to outsiders (the "external" market). (See Doeringer \& Piore, 1971, pp. 1-2). The present paper explores these insights with respect to academia and hence is related to an emerging literature dealing with "academic labour markets." Much of this writing (e.g., Roemer \& Schnitz, 1982; Smith \& Hixon, 1987; Brenneman \& Youn, 1988) approaches the topic from the prospective of dual labour market thinking which crosscuts the occupation and organization distinctions we have put forward. The primary ("good jobs") and secondary ("bad jobs") labour market categories of dual labour market theorizing originally addressed problems of the urban poor who were disproportionately located in the secondary sector (see Doeringer \& Piore, 1971 pp. 163-183; Piore, 1973; Edwards, 1979, pp. 163-183). However, by identifying secondary labour market zones in modern universities, and the academics so located, recent research has come to recast this concept to embrace not only the untrained poor but some of the most highly educated people in contemporary society. A significant portion of these instructors, in a manner not dissimilar to the poor in secondary employments, experiences unstable, irregular, work assignments which add up to chaotic work histories in contrast to the more orderly careers of their colleagues in the primary sector. The latter corresponds closely to what we have identified as the internal labour market.

In the present paper, these concerns are addressed principally via the organizational domain of a modern research university. ${ }^{3}$ Our research objectives, however, embrace important points of intersection between organizational and occupational (especially professional) considerations (see Rosenblum \& Rosenblum, 1990). Our focus here on the employing organization as labour market emphasizes the salience of work setting for career experience. Thus, individuals with virtually identical occupational characterisitics may, nevertheless, experience vastly different careers depending on the employing organization to which they are attached (see Spilerman, 1977). We focus particularly on the importance of nature of appointment within an organization for overall work history.

The present paper will utilize this thinking in addressing the entire undergraduate teaching output at one university in one academic year. We will ask who teaches whom, when, where and under what circumstances. We define the internal labour market as those positions that are tenure-stream, i.e., tenured and tenure-track. Those located in such positions are considered for promotion to, or within, the professorial ranks without having to contend with all potential competitors including aspirants not currently employed within that particular 
setting. Such competition characterizes the external market which comprises all others and this includes the overwhelming majority of part-time appointees, as well as those with non-tenure track, full-time appointments, who normally can make no such claims for promotional consideration. The tenure-stream appointee enjoys the aforementioned shelter which relieves him or her of the necessity of contending with all competitors possessing similar, or even superior, credentials.

Those in the external labour market are far more varied than internal labour market appointees with respect to age, qualifications (degree and other), nature and extent of involvement in other jobs, and family and other vocational or artistic activities. Some bring special skills, expertise and/or contacts to their teaching which are extremely useful to their students. Some wish the shelter of the internal labour market and others do not (Baker, 1985; Warme \& Lundy, 1988). Among those who do not, some are retired, others have a career apart from teaching, and others have a range of non-work interests and activities (see Tuckman, 1978, for a relevant typology among part-timers.) Also, some are part-timers and some are full-time. While full-time temporary appointees usually receive more benefits and teaching resources than do part-timers, what they share are unprotected statuses with respect to future work. As Linda Moffat (1980) documents, and discusses at length in Room at the Bottom, this job insecurity is highly salient and problematic to many contractually limited full-time appointees.

The theoretical framework we adopt lends itself readily to concerns with the experiences of different generations relative to career prospects (Easterlin, 1980; Oppenheimer, 1982; Tepperman, 1988). The ebb and flow of demand for academics has had important, and often lasting, effects on the respective fortunes of different cohorts, members of which have confronted different "tidal" phases of such demand at the outset of their careers. Generation or cohort as an aspect of one's life chances was early addressed by Ryder (1965) and such concerns have emerged as a major feature of recent age-related, such as life course, studies (e.g., Riley et al., 1988). Our data will provide some indications of the persistent difficulties faced by those who entered the work arena during a period of contraction and were therefore largely limited to external labour market positions from which it was difficult to escape and which gave rise to CV's that provided potential employers with ample (and stigmatizing) evidence of chaotic careers. The other side of the coin is the career progress experienced by the lucky ones who began during a period of buoyant opportunities and were carried along on the wave of such benign conditions. Interview evidence affirms 
that academics are well aware of, and can give voice to, the good fortune of accidents of birth (i.e., cohort membership) that have conspired to make their careers (Slaney, 1988, pp. 93-94, 152).

Aspects of gender in academia may be approached in a similar fashion. That the female labour force is both occupationally and industrially segregated is, at this point, well-documented (Connelly, 1978; Phillips \& Phillips, 1983; Armstrong \& Armstrong, 1984). The rising labour force participation of women was in large part in response to the emergence of certain "empty places" (a term coined by Baron \& Bielby, 1980, p. 737) which they came to occupy, and is a key to much labour market thinking on the subject. This thinking was early informed by the pioneering study of Oppenheimer (1970). Findings will be presented which document the very major part external labour market positions play in academic women's careers, a much greater part than they play in the careers of men.

In the arena of academia, as in the realm of professional and expert services in general, the segmentation of the market is likely to have some relationship to varying characteristics of clienteles. What we are suggesting is that specific categories of students are disproportionately served by specific categories of instructors, a substantial proportion of whom are relatively disadvantaged with respect to resources for teaching. Thus, some of the answer to the question of who performs what services for whom can be obtained by analyzing market location. The present effort will have something, although tentative and preliminary, to say not only about who ends up in which market location but about the nature of the clients (i.e., students) that they serve.

What is of major importance here are the structural arrangements surrounding the work of the two categories of instructors, which are related to labour market location. These have importance for instructors' ability to teach as well as their job satisfaction. Job insecurity, along with lack of office space, secretarial support, minimal notification time prior to teaching assignments as well as actually being hired very shortly before a course begins are all very well documented features of the experience of many part-time instructors and some are features of contractually limited appointments as well (Abel, 1984; Smith \& Hixson, 1987; University of Alberta, 1989; Rosenblum \& Rosenblum, 1990). These clearly make teaching more difficult for many in the external labour market. ${ }^{4}$ Even so simple a matter as lack of library privileges during the summer months has been found to impede part-timers' course preparation as well as their own scholarly undertakings (University of Alberta, 1989, p. 13). Thus, it is the differing structural arrangements for the provision of instruction to different categories of students with which we are concerned. 
While data about the characteristics of external labour market instructors over time are lacking, it does appear that there have been shifts in this population, the most recent of which likely has been a significant increase in the proportion of Ph.D.'s (caused by the lack of opportunities to enter internal labour markets of universities due to fiscal constraints). Similarly, there appear to be important changes in the ways in which universities make use of these positions as part of their strategies for dealing with fiscal constraint. What has largely endured is the social structure of these external labour market jobs, their lack of security, and the almost exclusive focus upon teaching courses in exchange for remuneration with few, if any, other obligations attaching to employer or employee.

The developing rules and regulations surrounding the use of external labour market appointments are both hotly contended and of substantial importance in determining the evolving nature of contemporary universities. In recent discussions of non-tenure stream teaching, and occasionally in research thereon, the interests of one category of non-tenure stream instructor is stressed to the detriment, or at least neglect, of others. Thus, methodological issues such as completeness of personnel lists, variations among institutions, and, when relevant, response rates (including variations of response rates among categories of instructors) are of considerable importance in the emerging literature on this topic. As we begin to have information about external labour market instructors, failure to deal successfully with these issues can lead to overlooking the situations of many less vocal such instructors, and thus possibly to formulating policies which do them substantial disservice. The focus of this paper on developing complete lists of all who offer courses regardless of how they are classified by the university is a necessary step in being fully cognizant of all those engaged in this important work.

\section{Empirical Findings}

Our concern with the providers of expert services, recipients and organizational contexts led us to a research design which yields information about all three. Most of the findings presented are based upon data collected about each undergraduate course (1,782 in all) offered at one mid-sized Ontario university ${ }^{5}$ in the 1986-7 academic year and about each instructor (721 in all) so located. (We omitted from our tabulations faculty who did not offer undergraduate courses during the academic year.) One of our goals was to determine the feasibility of preparing a list of all instructors in this way. Two different units of analysis will be reported upon - courses and instructors. 
The sources consulted about courses and instructors at the subject university include timetables, university calendars, personnel lists of all full-time employees and records of room utilization, the latter two of which were generously released to us by the university. In addition, we also relied upon communications with departmental co-ordinators and secretaries. Routine cross-checking of information was central to our procedures and brought to our attention a considerable number of discrepancies which had to be resolved and many "special" arrangements we had not foreseen or been aware of. Our sources of information provided us with the department, level, units, enrolment, term, time and location of each course, as well as the nature of appointment of each instructor and the age and gender of all full-time instructors and of $75 \%$ of those who were part-time.

Table 1 presents the distribution of both courses and instructors by nature of appointment and documents the very major presence of external labour market instructors in undergraduate teaching. Twenty percent of all such courses are offered by these instructors who account for fully $27 \%$ of all the personnel. Sixty-four percent of all courses are offered by tenured professors who make up an almost identical proportion, $63 \%$, of all instructors. Tenure track instructors account for $11 \%$ of all courses and $10 \%$ of all instructional personnel. Thus, only slightly less than $75 \%$ of all instructors are in the internal labour market and they teach $75 \%$ of all courses. The remaining quarter of all courses and personnel are accounted for by other arrangements. Contractually limited appointments account for six percent of all courses and five percent of all instructors. Five percent of all courses were either "directed research," "ensemble," (a Music Department designation) or staffed by teaching assistants. The first two categories are included, with courses taught by internal labour market instructors, in the discussion which follows, specifically Tables 2 and 3. (Almost all directed research courses are taught by internal labour market faculty as are a major proportion of the very small number of the ensemble courses).

Part-timers, who, not surprisingly, carry somewhat lower course loads than full-timers, account for $14 \%$ of all courses and fully $22 \%$ of all instructors. Our location of 155 part-timers among the 721 involved in undergraduate teaching is important. While tenured professors' major role in teaching is salient to all, the presence of part-timers (here considerably more numerous than all other nontenured faculty combined) remains largely invisible as do their concerns and work situations. (Tuckman et al., 1978, p. 186; Leslie, et al., 1982, p. 143). Numerous organizations and individuals have asked for recognition and study of the work of part-timers, (Tuckman, 1981, p. 8; Gappa, 1984, p. 95) as well as 
Table 1

Distribution of courses and instructors by labour market status of instructor

\begin{tabular}{|c|c|c|c|c|}
\hline \multirow[b]{2}{*}{ Tenured } & \multicolumn{2}{|c|}{$\begin{array}{l}\text { Percent of } \\
\text { all courses* }\end{array}$} & \multicolumn{2}{|c|}{$\begin{array}{c}\text { Percent of } \\
\text { all instructors } \\
\text { (excluding teaching } \\
\text { assistants) }\end{array}$} \\
\hline & $64 \%$ & & $63 \%$ & \\
\hline Tenure Track & $11 \%$ & & $10 \%$ & \\
\hline Internal Labour Market & & $75 \%$ & & $73 \%$ \\
\hline Contractually limited & $6 \%$ & & $5 \%$ & \\
\hline Part-timers & $14 \%$ & & $22 \%$ & \\
\hline External Labour Market & & $20 \%$ & & $27 \%$ \\
\hline Teaching Assistants & $1 \%$ & & & \\
\hline Ensemble or Directed Research & $4 \%$ & & & \\
\hline
\end{tabular}

Number of Courses $=1,782$

Number of Instructors $=721$

* Courses are defined by entries in time schedules. "Directed Research" and "Thesis" courses are grouped by each department under one or two course numbers at the subject university and were counted in this manner.

their inclusion in routine data collection about faculty. (See particularly Breslauer, 1985, p. 86.) As indicated, these omissions, and consequent distortions, in studies of universities are being remedied along a number of fronts and the present effort is seen as a contribution to this emerging literature.

Tables 2 and 3 are based upon the 1,782 undergraduate courses offered. Table 2 shows that lower level courses are more likely to be taught by external labour market instructors than are others, with $25 \%$ of all first year courses so taught as compared with $14 \%$ of fourth year courses. Table 3 shows greater discrepancies, with off-hour, summer and off-campus courses considerably more likely to be taught by external labour market instructors than are the more conventional week-day, September-to-June on-campus courses. While 17\% of all weekday courses are staffed by the external labour market, $35 \%$ of courses in all other time slots are so staffed. The external market staffs $52 \%$ of all summer 
Table 2

Labour market status of instructor by course level

\begin{tabular}{|c|c|c|c|c|}
\hline & First & Second & Third & Fourth \\
\hline Market Status & Year & $\underline{\text { Year }}$ & Year & Year \\
\hline Internal Labour Market & $70 \%$ & $77 \%$ & $80 \%$ & $86 \%$ \\
\hline External Labour Market & $25 \%$ & $21 \%$ & $20 \%$ & $14 \%$ \\
\hline \multirow[t]{2}{*}{ Teaching Assistants } & $\underline{5 \%}$ & $\underline{2 \%}$ & $\underline{0 \%}$ & $\underline{0 \%}$ \\
\hline & $100 \%$ & $100 \%$ & $100 \%$ & $100 \%$ \\
\hline Number of courses & 285 & 499 & 535 & 463 \\
\hline
\end{tabular}

Table 3

Labour market status of instructor by selected characteristics of courses

Time Slot Term $\underline{\text { Location }}$

Weekday Other Sept-June Summer On Campus Off Campus

Internal

Labour

Market

$81 \%$

$61 \%$

$80 \%$

$47 \%$

$77 \%$

$41 \%$

External

Labour

Market

$17 \%$

$35 \%$

$18 \%$

$52 \%$

$20 \%$

$59 \%$

Teaching

Assistants

$2 \%$

$1 \%$

$2 \%$

Ensemble

$$
\frac{1 \%}{100 \%} \quad \frac{4 \%}{100 \%} \quad \frac{1 \%}{100 \%} \quad \frac{1 \%}{100 \%} \quad \frac{1 \%}{100 \%} \quad \frac{}{100 \%}
$$

Number of

courses

1,422

329

1,646

116

1,713

29

courses (in contrast with $18 \%$ of those offered between September and June) and fully $59 \%$ of the relatively small number of off-campus courses, in contrast with $20 \%$ of those offered on campus. Thus students taking lower level courses, and the off-hour or summer courses are relatively more likely than others to encounter external labour market instructors (along with their possible attendant problems with room assignments, office space, secretarial support). 
As is well-known, part-time students take these off-hour, off-campus courses much more frequently than others. Data routinely collected by the subject university document that part-time students are on average a full decade older than full-time students, and are disproportionately enrolled at lower year levels, and that women constitute fully $70 \%$ of their total in contrast with slightly less than $50 \%$ of full-time students. These patterns are similar to those found in almost all scrutinies of characteristics of full-time and part-time students (see, for example, Belanger \& Omiecinski, 1987, p. 24; Anisef, 1989, p. 22,). Thus, it is the older, heavily female, population of part-time students who disproportionately take off-hour, off-campus courses, and most frequently encounter external labour market instructors in these settings. This brings to our attention that a somewhat different "clientele" is more likely to be taught by external labour market instructors, a pattern which "resonates" with those found with respect to the legal profession (e.g., Carlin \& Howard, 1965) as well as other scrutinies of universities (Abel, 1987, p. 74-80). While these findings are suggestive rather than conclusive, what they indicate is of major importance: that with respect to the distribution of professional or knowledge-based services, specific categories of recipients are disproportionately served by specific categories of practitioners in work situations which are meaningfully different from those in which such services are rendered to others. Our data indicate that the rapidly expanding category of part-time students, a larger proportion of whom enroll in off-campus, off-hour and lower level courses, are more likely than others to encounter nontenure stream instructors. Despite the truly excellent instruction many of these instructors provide, it has been well-documented that the structure of the employment relationship for those in the external labour market raises meaningful obstacles to providing instruction comparable to that provided from within the tenure stream. These obstacles include the widespread prevalence of job insecurity, very late notification of teaching assignments (with little of no remuneration if courses are cancelled), lesser availability of secretarial support, office space, telephones and library privileges (Leslie et al., 1982, pp. 80-81, 103; Gappa, 1984, pp. 65-67; Rajagopal \& Farr, 1989, p. 279; University of Alberta, 1989, p. 13). Clearly such patterns are of major importance today and must be further researched in academia as well as with respect to the provision of other expert services.

It is of interest to note that while there are substantial differences between faculties in their use of external labour market personnel, these instructors are, nonetheless, a major presence in all faculties of the subject university. External labour market instructors taught $12 \%$ of the Science and $13 \%$ of the Engineering 
Table 4

Kind of appointment by gender and age

\begin{tabular}{|c|c|c|c|c|c|c|}
\hline & Total & $\begin{array}{l}\text { Less than } \\
35 \text { years }\end{array}$ & $\begin{array}{c}35 \text { to } 44 \\
\text { years }\end{array}$ & $\begin{array}{c}45 \text { to } 54 \\
\text { years }\end{array}$ & $\begin{array}{c}55 \text { to } 64 \\
\text { years }\end{array}$ & $\begin{array}{l}65 \text { years } \\
\text { or more }\end{array}$ \\
\hline Tenured & $73 \%$ & $6 \%$ & $65 \%$ & $93 \%$ & $96 \%$ & $50 \%$ \\
\hline Tenure Track & $10 \%$ & $48 \%$ & $13 \%$ & $1 \%$ & $1 \%$ & $0 \%$ \\
\hline Internal Labour & $-\cdots-$ & $-\cdots$ & $-\cdots$ & $-\cdots--$ & ---- & \\
\hline $\begin{array}{l}\text { Market } \\
\text { Contractually }\end{array}$ & $83 \%$ & $54 \%$ & $78 \%$ & $94 \%$ & $97 \%$ & $50 \%$ \\
\hline Limited & $4 \%$ & $11 \%$ & $6 \%$ & $0 \%$ & $0 \%$ & $7 \%$ \\
\hline Part-Time & $13 \%$ & $35 \%$ & $16 \%$ & $6 \%$ & $3 \%$ & $43 \%$ \\
\hline External Labour & $\cdots$ & 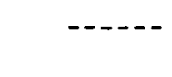 & ---- & 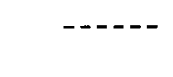 & $-\cdots$ & $-\ldots-$ \\
\hline Market & $17 \%$ & $46 \%$ & $22 \%$ & $6 \%$ & $3 \%$ & $50 \%$ \\
\hline Total & $100 \%$ & $100 \%$ & $100 \%$ & $100 \%$ & $100 \%$ & $100 \%$ \\
\hline$N=$ & 563 & 72 & 174 & 198 & 105 & 14 \\
\hline
\end{tabular}

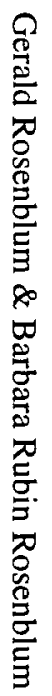


Table 4 (continued)

Female

Tenured

Tenure Track

Total

Less than

35 to 44

45 to 54

55 to 64

65 years

35 years

years

years

years

or more

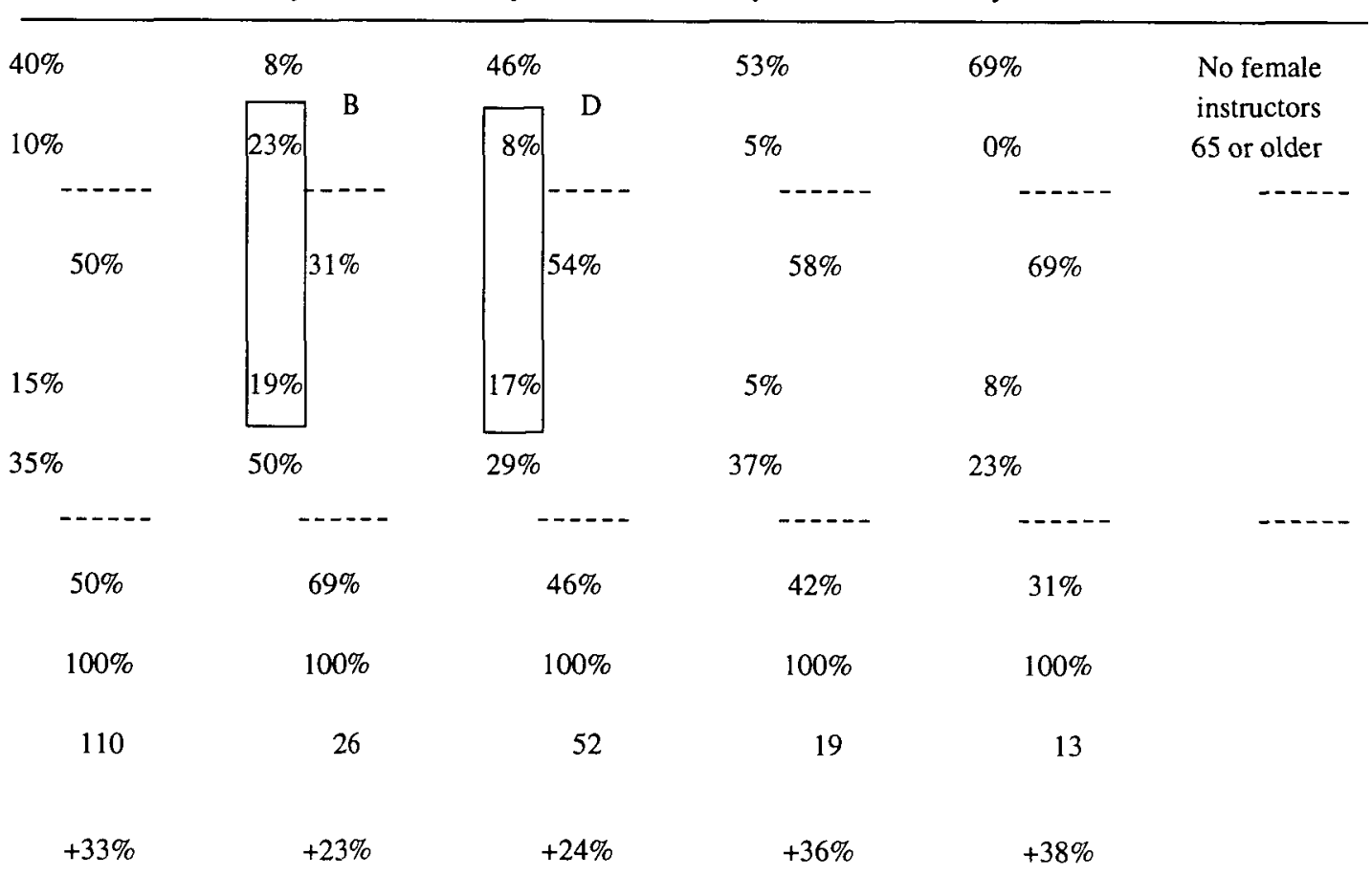

Difference between

Males \& Females in the Internal Labour Market

Internal Labour

Market

Contractually

Limited

Part-Time

External Labour

Market

Total 
Table 5

Percent of tenured faculty who have Ph.D. by age and gender

\begin{tabular}{lcccc} 
& $\begin{array}{c}35 \text { to } 44 \\
\text { years }\end{array}$ & $\begin{array}{c}45 \text { to } 54 \\
\text { years }\end{array}$ & $\begin{array}{c}55 \text { to } 61 \\
\text { years }\end{array}$ & $\begin{array}{c}65 \text { or more } \\
\text { years }\end{array}$ \\
\cline { 2 - 5 } Male & $87 \%$ & $92 \%$ & $85 \%$ & $43 \%$ \\
& $(113)$ & $(185)$ & $(101)$ & $(7)$ \\
Female & $83 \%$ & $60 \%$ & & \\
& $(24)$ & $(100)$ & $44 \%$ & \\
\hline
\end{tabular}

courses, $22 \%$ of those in Humanities and $24 \%$ of those in Social Sciences. With respect to Commerce (which accounts for $8 \%$ of all courses) external labour market instructors taught $43 \%$ of the courses. The differences that do exist between the faculties are not inconsistent with the impressions of many that different faculties predominantly utilize differently situated external labour market personnel (e.g., Commerce likely employs a far greater proportion of those who are full-time employed elsewhere than the other faculties).

Table 4 looks at the instructors as the unit and informs us that the external labour market is staffed primarily by the young and disproportionately by women. This study, like others, finds that a majority of those in the external labour market are men, but that a far larger percentage of women than men are in this less sheltered market. Overall, only $50 \%$ of all women instructors were found to be in the internal labour market, while fully $83 \%$ of the male instructors were so located. These findings are consonant with the considerable body of research about academia which documents women's disproportionate presence in less advantaged statuses, particularly those in the external labour market. (Such research includes Fulton, 1975; Kantrowitz, 1981; Abel, 1984; Warme \& Lundy, 1986; Simeone, 1987; Chamberlain, 1988). We do not argue that labour market allocation entirely accounts for the nature of women's experiences in academe. (See Guppy, 1989, p. 753, who makes this point explicitly). However, this table does document that labour market status does have a very major impact on academic women's career trajectories.

While each advancing age category in Table 4 shows a far higher percentage in the internal labour market, in all cases the percentage of females in the internal market is very substantially lower than that of males. See, for example, the bottom row of Table 4 for the percent differences which are at minimum 23 . In no case is the percentage of women in the internal market any higher than the 
percentage of males in the next younger category. Thus, women's greater presence in the external market is found to be very substantial at all ages, and the reasons for this must be further explored. It is clearly something apart from women's newcomer status which accounts for this often documented pattern. The finding that academic women's life course patterns (e.g., age of obtaining $\mathrm{Ph} . \mathrm{D}$., and entering and proceeding through the internal labour market) differ considerably from men has been documented and discussed by many commentators. (See, for example, Bernard, 1964; Astin, 1971; Aisenberg \& Harrington, 1988.) This is further supported by our finding that within each age category, and among those with tenure, women were less likely than men to have the Ph.D. (See Table 5). This is not a simple finding, because among all instructors with Ph.D.'s, women are also less likely than men to have tenure. It is one more indication that the career patterns of women in academia are far more diverse than those followed by men. The increasing individualization of women's lives is the subject of Jones, Marsden and Tepperman's Lives of Their Own (1990). In addition, Larry Hirschhorn (1977) along with researchers concerned with increasing longevity (Rossi, 1980; Riley, 1985) have observed that the life courses of men are also becoming increasingly varied, although not to the same extent as those of women. Carol Gilligan's point that "when life cycle theorists equally divide their attention and begin to live with women as they have lived with men [then] will their vision encompass its experiences of both sexes and their theories become correspondingly more fertile" $(1979$, p. 445$)$ is well-taken in connection with the study of academia.

Another finding pertaining to diverse life course patterns has to do with the entirely male category of instructors 65 and older in Table 5, half of whom are teaching in the external labour market. This accords with our finding in an earlier phase of this research that "semi-retired" have been obtaining an increasing proportion of external labour market appointments during the past decade. Clearly older academics, likely mostly men, are contributing significantly to non-tenure stream teaching. While this group provides students with exceptional experience and proven ability, their growing numbers may be occurring at the expense of youthful aspirants seeking an initial foothold in academe (Rosenblum \& Rosenblum, 1990).

It is also of interest to contrast two specific categories of full-time appointments in Table 4, tenure track and contractually limited, to explore the patterns of age and gender variations. We focus specifically upon the two most youthful categories and contrast the two above-mentioned kinds of non-tenured appointments to learn more about entry to the internal market. Within each age 
category, the ratio of tenure track to contractually limited appointments is substantially greater for men than for women. For those less than 35 the ratio is $48 \%: 11 \%$ or 4.36 for men in contrast with $23 \%: 19 \%$ or 1.21 for women. (Box A is contrasted with Box B.) Thus, men have more than four tenure track appointments for each contractually limited slot, while women have only slightly more than one. For those 35 to 44 years of age, the figures are 13\%:6\% or 2.17 for men in contrast with $8 \%: 17 \%$ or 0.47 for women - Box C in contrast with Box D. Thus, limiting ourselves to non-permanent full-time appointments, we find that, at each age, men obtain a far greater proportion of those jobs which are ports of entry to the internal labour market.

We also contrast these ratios for differences between these two age categories. We find that it is in the very youngest age category that the entry positions are the most prevalent. That is, the ratio of tenure track to contractually limited appointments is considerably higher for those under 35 than for those in the 35 to 44 age category for each gender. (Box A, 4.36 must be contrasted with C, 2.17 for men, while Box B, 1.21 is contrasted with $\mathrm{D}, 0.47$, for women.) Thus, a full-time instructor who is untenured between 35 and 44 is more likely than a similarly circumstanced younger academic to be in the external labour market. This does provide some support for the notion of a "lost generation" of academics who obtained their Ph.D.'s in the seventies, some of whom are still in contractually limited appointments and who appear to be less likely to obtain tenure track appointments than more recent Ph.D.'s. Clearly, the interplay between gender, generation and life course must be further explored.

We close our empirical section with some discussion of the extent to which findings about the external labour market at the subject university may be similar to those at other universities in Ontario and beyond. ${ }^{6} \mathrm{~A}$ very major and consistently acknowledged benefit of external labour market instructors, who are hired and fired when needed, is the great flexibility they provide universities to deal with funding uncertainties and many other unpredictable situations. ${ }^{7}$ (The second consistently acknowledged benefit is that they are paid far less than those in the internal market.) These patterns of increased use of external labour market instructors parallel those in the broader society pertaining to the growth of "'non-standard work forms'..... [which] have increased their share of total employment in recent years." (Economic Council of Canada, 1990, p. 11) Discussions of these patterns are usually concerned with the growing polarization within the job structure as well. While non-standard work is often found to be prevalent at low skill and education levels, and among minority populations, the polarization of academia itself, and other highly prestigious areas of 
Figure 1

Percent contractually limited appointments among full-time non-medical, non-dental appointments for selected mid-size Ontario universities and for Ontario, 1977-1986.*
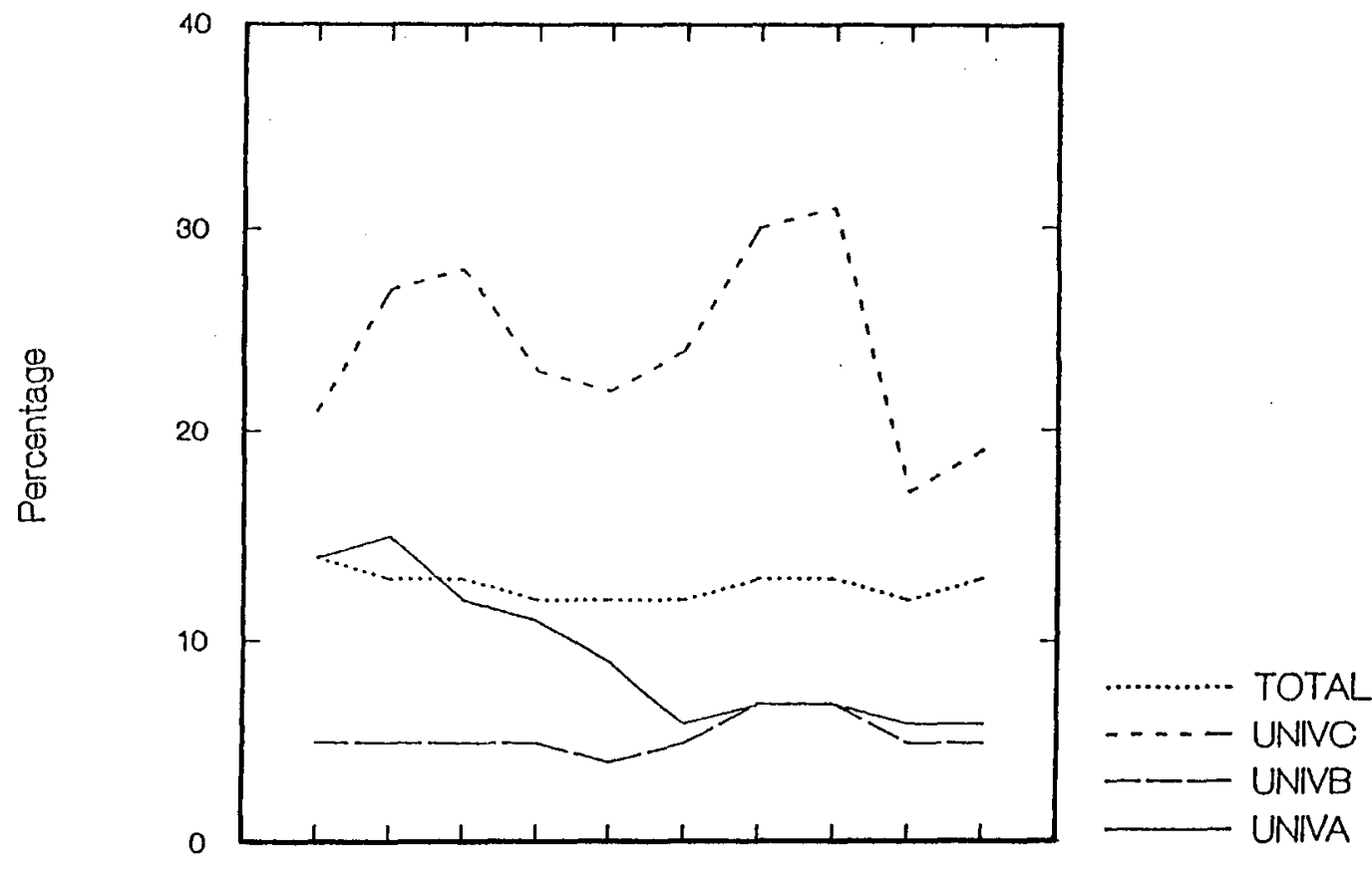

1977. 1978. 1978. 1880. 1981. 1982 1983. 1984 1985. 1888.

* Based on tabulations provided by Statistics Canada from their university full-time teaching staff file 
employment, into good and bad jobs is also being observed (Ehrenreich, 1989, p. 246; University of Alberta, 1989, pp. 14-15).

The flexibility afforded by external labour market instructors means that they are used in a range of different ways both among institutions and over time. Linda Moffat's study Room at the Bottom (1980) deals with the great increase in contractually limited appointments at a time of severe funding cutbacks. This pattern is also noted by Axelrod in his historical study of Ontario universities (1982, p. 187).

Figure 1 indicates that there were also considerable differences among midsized Ontario universities in their use of full-time contractually limited appointments. (As discussed earlier, it is unfortunate that no comparable statistics for part-timers are available at this time.) University A, the subject of our more detailed study, currently makes use of contractually limited appointments less than most, but not all, other Ontario universities. It decreased its use of such appointees between 1977 and 1986 from 14\% to 7\%. University B started from a far lower level of such appointments and maintained that level throughout the time period. In contrast, University $\mathrm{C}$ made far more extensive use of contractually limited appointments (which constitute more than $20 \%$ of full-time appointments) and has significantly varied their use throughout the decade in question.

We do have some evidence that wide variations in the use of part-timers are also characteristic of Canadian universities. For example, Warme and Lundy found, at a large metropolitan university in 1985-6, that part-timers accounted for $47 \%$ of all teaching personnel, and that part-timers and teaching assistants accounted for $45 \%$ of all teaching. (1988, p. 205) Clearly, this is a much greater presence than found in the mid-sized Ontario university reported on here. In the course of meeting with administrators at a number of Ontario universities, we have found many well aware of the different strategies that they and their counterparts elsewhere have for the use of external labour market faculty. Others have expressed considerable concern about learning more about their own and other universities' practices. While levels of information and concern vary considerably, it appears that faculty unions and associations are similarly wellinformed and concerned on some campuses.

\section{Discussion and Conclusions}

Both part-timers and non-tenure stream full-time appointments appear to be becoming increasingly important in contemporary universities. Tuckman and Pickerill (1988, p. 98) note the presence of a quarter million part-timers in U.S. academia in 1985. Focusing on Canada, Buchbinder and Newson (1985) 
identify three major processes associated with significant changes in the organization of academic work. The first of these dealing with the diversification of the academic workforce is concerned with "the systematic development of appointment categories...tenure track professors, contractually limited professors...and part-time professors...through conscious managerial policies designed to create fiscal and programmatic flexibility" (1985, pp. 230-231).

Our continuing research on Ontario universities informs us that many here share a concern for the constructive use of the external labour market, both in terms of the lives of the instructors and the instruction they provide. However, many different (and sometimes conflicting) strategies are being pursued, and much of what is currently being said about external labour markets in academe is emanating from specific interest groups and specific universities. (Two somewhat different views of the power of these different categories of university personnel are presented by Newson and Buchbinder, 1988 and Rajagopal and Farr, 1989.) While this emerging information is extremely valuable, there is a real need for an overall picture of the totality of university instruction provided by both labour markets. This article is an attempt to fulfill, in part, this need.

As we documented, there is wide variation among Ontario universities in their use of external labour market instructors. This has led to some projections for the future of university teaching which differ very substantially from current practices and goals at a significant number of such institutions. One possibly extreme projection is that:

...by the end of the century a change of staffing may well have occurred which will greatly change the nature of the university in this province. Universities would be employing a 'core' of full-time professors who would have multiple responsibilities (collegially deciding upon admissions, awards, the curriculum of programs and types of student assessment, but teaching only advanced courses and undertaking much more research) matched by a much greater number of part-time teachers whose real interests and occupational responsibilities lie outside the university. These part-time 'professors' would be simply engaged in piece work, on a fee per course basis, to instruct sets of students as directed by a core group of professors. (Watson, Quazi \& Stokes, 1985, p. 377)

These projections and their implications are clearly very important, on both a policy level and for those concerned with the social organization of labour markets and the delivery of expert services in contemporary society. 
The long, invisible, external labour markets of academe are now beginning to be counted and included systematically in discussions of labour sources and needs. At the same time, projections and policy proposals are being made based upon the experiences of a very small number of institutions. Careful studies of a range of universities (differing in size, degree of centralization, disciplinary strengths and research orientation) are needed, and the work reported on here is part of such an endeavour.

It has been our intention to develop the utility of, and to employ, the perspective of segmented labour market theorizing in confronting instruction in institutions of higher learning. In brief, we have attempted to address the organizational labour market of contemporary universities as a means of coming to grips analytically and empirically with the determinants and consequences of variations in instructional conditions in such settings. Our focus on the employing organization as labour market alerts us to the importance of work setting for the varying career futures of a labour force. As asserted at the outset, one's career prospects are not pre-ordained by one's occupational status, however important that may be. Our own work finds that there are significant, patterned, differences in the employment experience of instructional staff of the contemporary university that are real in their consequences and that can be initially approached by identifying market segments within the overall structure. One middle sized university in Ontario serves as a case study to establish the utility of a labour market approach to the subject of the occupation of university instructor while demonstrating that the market categories that we've depicted can be empirically realized in a concrete setting. We have further demonstrated, in this setting, that members of the different market categories are differentially distributed by course level, by time slot and by location. In addition, we have shown that labour market categories differ by age and by gender.

Though our data indicate a pronounced status differential between male and female faculty, the causal basis for this differential cannot be discerned entirely from the information at hand. Given the data available on life course differences between members of the two groups, we have reason not to settle prematurely upon different treatment of men and women within the employing organization as the sole basis for observed career differences - not without exploring the matter further which should include eliciting testimony from those concerned.

The issues addressed here, common to universities across North America, point up the importance of organizational attachment for the production and delivery of professional and expert services in contemporary society. Thus, while our primary research emphasis has, ironically, been with the occupation 
of university instructor, we have demonstrated that one cannot pursue that matter very far without confronting the organizational matrix within which this occupation lives.

\section{Notes}

*This research was supported by a SSHRC Strategic Seed Money Grant entitled External Labour Markets in Academia: Work and Social Structure. We very much appreciate the able research assistance of Brad LaForme, Lillian Giavodoni, and Brenda Nussey as well as the tabulations provided by Dev Uppal of the Post-Secondary Section, Education, Science and Culture Division of Statistics Canada. Considerable advice was generously provided by Gord Raymond, Co-ordinator of Part-Time Degree Studies at McMaster Univeristy and Wilf Ward, Director of McMaster's Office of Institutional Analysis. The authors, however, take sole, and full, responsibility for the ultimate rendering of all this help in the present document, portions of which were presented at the Annual Meetings of the Ontario Analysis and Planning Group, London, Ontario, 1990 and the Class Bias and Higher Education Conference, Queens College, City University of New York, 1990.

1 See, for example, Conseil des Universités, Québec (1989) and Rajagopal and Farr (1990). For a description of research currently underway see Rajagopal and Farr, 1992 , p. 319.

2 One of the earliest formulations of these arenas appeared in the now-classic statement by Clark Kerr (1954).

3 Freidson (1986) has strongly emphasized the increasing role of organizations in the conduct of contemporary professions.

4 The few research findings about students' perceptions of marginal instructors, usually limited to part-timers, have failed to document any consistent negative findings and have usually been equivocal (Lundy \& Warme, 1989, p. 75). They are clearly not sufficient to lead us to dismiss the impact of the situation of part-timers and contractually limited instructors on their teaching, but instead should lead us to learn more about how this teaching is accomplished despite the frequent lack of resources.

5 Mid-sized universities in Ontario are here defined as having between 500 and 1,000 non-medical and non-dental full time instructional staff.

6 Ontario contains three very large universities, each with full-time enrollments of almost 20,000 or more, five small univerisities with full-time enrollments of less than 6,000 and seven, including the subject university, with enrollments between 9,500 and 16,000 (Ontario Ministry of Colleges and Universities, 1991, pp. 94-149). In common with roughly half the universities in Ontario, the subject university is within communting distance of Toronto, and can, and does, draw both internal and external labour market instructors from that area.

7 The flexibility provided by the range of differing employment relationships of instructors is also discussed in somewhat different terms by Tancred-Sheriff (1985, pp. 374-5). 


\section{References}

Abel, E.K. (1984). Terminal degrees: The job crises in higher education. New York: Praeger Publishers.

Aisenberg, N., \& Harrington, M. (1988). Women of academe: Outsiders in the sacred grove. Amherst, MA: The University of Massachusetts Press.

Anisef, P. (1989). Studying part-time in Canada's universities: A perspective in social change. The Canadian Journal of Higher Education 19, 11-28.

Armstrong, P., \& Armstrong, H. (1984). The double ghetto. rev. ed. Toronto: McClelland and Stewart Ltd.

Astin, H.S. (1969). The woman doctorate in America. New York: Russell Sage Foundation.

Axelrod, P. (1982). Scholars and dollars: Politics, economics and the universities of Ontario, 1945-1980. Toronto: University of Toronto Press.

Baker, M. (1985). Teacher or scholar? The part-time academic. Society/Societé 9, 3-7.

Baron, J.N., \& Bielby, W.T. (1980). Bringing firms back in: Stratification, segmentation, and the organization of work. American Sociological Review 45, 737-765.

Belanger, R., \& Omiecinski, T. (1986). Part-time university enrollments. Canadian Social Trends (Statistics Canada) 11-008E, 22-25.

Bernard, J. (1964). Academic women University Park: Pennsylvania State University Press.

Breneman, D.W., \& Youn, T., (eds.). (1988). Academic labor markets and careers. New York: The Falmer Press.

Breslauer, H.J. (1985). Women in the professoriate - The case of multiple disadvantages. In The professoriate - Occupation in crisis. Toronto: Ontario Institute for Studies in Education.

Buchbinder, H., \& Newson, J. (1985). The academic work process, the professoriate and unionization. In The professoriate - Occupation in crisis. Toronto: Ontario Institute for Studies in Education, pp. 221-247.

Carlin, J.E., \& Howard, J. (1965). Legal representation and class justice. U.C.L.A. Law Review 12, 381-437.

Chamberlain, M.K. (1988). Women in academe: Progress and prospects. New York: Russell Sage Foundation.

Connelly, P. (1978). Last hired, first fired. Toronto: The Women's Press.

Conseil des universités, Québec. (1989). Les chargés de cours dans les universités québécoises. Sainte-Foy, Québec: Gouvernement du Québec.

Doeringer, P.B., \& Piore, M.J. (1971). Internal labour markets and manpower analysis. Lexington, Mass: D.C. Heath and Co.

Easterlin, R.A. (1980). Birth and fortune: The impact of numbers on personal welfare. NY: Basic Books, Inc.

Economic Council of Canada. (1990). Good jobs, bad jobs: Employment in the service economy. Ottawa: Minister of Supply and Services.

Edwards, R. (1979). Contested terrain: The transformation of the workplace in the twentieth century. New York: Basic Books. 
Ehrenreich, B. (1989). Fear of falling: The inner life of the middle class. New York: Pantheon Books.

Freedman, M. (1976). Labor markets: Segments and shelters. Montclair, NJ Allanheld, Osmun and Co.

Freidson, E. (1986). Professional powers: A study of the institutionalization of formal knowledge. Chicago: University of Chicago Press.

Fulton, O. (1975). Rewards and fairness: Academic women in the United States. In Martin Trow (Ed.), Teachers and students (pp. 199-248). New York: McGraw Hill Book Company.

Gappa, J.M. (1984). Part-time faculty: Higher education at a crossroads. Washington, DC, Association for the Study of Higher Education.

Gilligan, C. (1979). Women's place in man's life cycle. Harvard Educational Review, $49,431-446$.

Guppy, N. (1989). Pay equity in Canadian universities, 1972-3 and 1985-6. Canadian Review of Sociology and Anthropology, 26, 743-758.

Hirschhorn, L. (1977). Social policy and the life cycle: A developmental perspective. Social Service Review, 51, 434-450.

Jones, C., Marsden, L., \& Tepperman, L. (1990) Lives of their own: The indivualization of women's lives. Toronto: Oxford University Press.

Kantrowitz, J. (1981). Paying your dues, part-time. In Gloria De Sole \& Lenore Hoffman, (Eds.), Rocking the boat: Academic women and academic processes (pp. 15-36). New York: The Modern Languages Association of America.

Kerr, C. (1954). The balkanization of labor markets. In E. Wright Bakke, et al.,(Eds.), Labor mobility and economic opportunity, (pp. 91-110). Cambridge and New York: Technology Press of the Massachusetts Institute of Technology and John Wiley and Sons, Inc.

Leslie, D.W., Kellams, S.E., \& Gunne, G.M. (1982). Part-time faculty in American higher education. New York: Praeger Publishers.

Lundy, K.L.P., \& Warme, B. (1989). Part-time faculty: Student perceptions and experiences. The Canadian Journal of Higher Education, 19, 73-85.

Moffat, L.K. (1980). Room at the bottom: Job mobility opportunities for Ontario academics in the mid-seventies. Queen's Park, Toronto: The Minister of College and Universities.

Newson, J., \& Buchbinder, H. (1988). The university means business. Toronto: Garamond Press

Ontario Ministry of Colleges and Universities. (1991). Horizons: Guide to postsecondary education in Ontario 1992-3. Queen's Park, Toronto

Oppenheimer, V.K. (1970). The female labour force in the United States. Berkeley: University of California Press.

Oppenheimer, V.K. (1982). Work and the family: A study in social demography. New York: Academic Press.

Phillips, P., \& Phillips, E. (1983). Women and work. James Lorimer \& Co.

Piore, M.J. (1973). Notes for a theory of labor market stratification. In R.C. Edwards, M. Reich, \& D.M. Gordon (Eds.), Labor Market Segmentation, (pp. 125-150). Lexington Mass.; D.C. Heath and Co. 
Rajagopal, I., \& Farr, W.D. (1989). The political economy of part-time academic work. Higher Education, 18, 267-285.

Rajagopal, I., \& Farr, W.D. (1990). Part-time faculty in Ontario Universities, 1987-88. A survey research study commissioned by the Committee on the Status of Women, Council of Ontario Universities

Rajagopal, I., \& Farr, W.D. (1992). Hidden academics: The part-time faculty in Canada. Higher Education, 24(3), 317-329

Riley, M.W. (1985). Women, men and the lengthening life course. In A.S. Rossi (Ed.), Gender and the life course, (pp. 333-347). New York: Aldine.

Riley, M.W., Foner, A., \& Waring, J. (1988). Sociology of age. In N.J. Smelser (Ed.) Handbook of sociology, (pp. 243-290). Newbury Park, Calif.: Sage Publications.

Roemer, R.E., \& Schnitz, J.E. (1982). Academic employment as day labor: The dual labor market in higher education. Journal of Higher Education, 53, 514-531.

Rosenblum, G., \& Rosenblum, B.R. (1990). Segmented labor markets in institutions of higher learning. Sociology of Education, 63, 151-164.

Rossi, A.S. (1980). Life span theories and women's lives. Signs: Journal of Women in Culture and Society, 6, 4-32.

Rossi, A.S. (ed.). (1985) Gender and the life course. New York: Aldine Publishing Co.

Ryder, N.B. (1965). The cohort as a concept in the study of social change. American Sociological Review, 30, 843-861.

Simeone, A. (1987). Academic women: Working toward equality. South Hadley, Mass.: Bergen and Garvey, Publishers, Inc.

Slaney, W. (1988). Controlling the autonomous: An exploratory case study of the mechanisms of control surrounding the achievement of status in academia. Unpublished M.A. Thesis. McMaster University, Hamilton, Ontario.

Smith, C.B., \& Hixon, V.S. (1987). The work of the university professor: Evidence of segmented labor markets inside the academy. Current Research on Occupations and Professions, 4, 159-180.

Spilerman, S. (1977). Careers, labour market structure, and socioeconomic achievement. American Journal of Sociology, 83, 551-593.

Tancred-Sheriff, P. (1985). Craft, hierarchy and bureaucracy: Modes of control of the academic labour process. Canadian Journal of Sociology, 10, 369-390.

Tepperman, L. (1988). Choices and chances: Sociology for everyday life. Toronto: Holt Rhinehart and Winston of Canada.

Tuckman, H.P. (1981). Part-time faculty: Some suggestions of policy. Change, 13, 8-10.

Tuckman, H.P., Caldwell, J., \& Vogler, W. (1978). Part-timers and the academic market of the eighties. The American Sociologist, 13, 184-195.

Tuckman, H.P., \& Pickerill, K.L. (1988). Part-time faculty and part-time academic careers. In D.W. Breneman \& T. Youn, (Eds.), Academic labor markets and careers, (pp. 98-113). New York: The Falmer Press.

University of Alberta Ad Hoc Committee to Study Temporary Academic Staff. (1989). Interim discussion paper - November. Unpublished document.

Warme, B., \& Lundy, K. (1988). Erosion of an ideal: The presence of part-time faculty. Studies in Higher Education, 13, 201-213. 
Warme, B., \& Lundy, K.L.P. (1986). Part-time faculty: Institutional needs and career dilemmas. In K.P. Lundy \& B. Warme (Eds.), Work in the Canadian context: Continuity despite change,(pp. 132-148). Toronto and Vancouver: Butterworths.

Watson, C., \& Quazi, S. with Stokes, N. (1985). Future implications of the age structure of the Ontario professoriate. The Professoriate - Occupation in Crisis, 366-390. Toronto: Ontario Institute for Studies in Education. 